\title{
Pengaruh Motivasi dan Pengetahuan UU No.5 Tahun 2011 Pada Minat Mahasiswa Akuntansi Mengikuti Ppak
}

\author{
Putu Ayu Bella Febryanti $\mathbf{A}^{1}$ \\ Ketut Alit Suardana ${ }^{2}$
}

\author{
${ }^{1}$ Fakultas Ekonomi dan Bisnis Universitas Udayana (Unud), Bali, Indonesia \\ email: febryantibella19@gmail.com/Telp : 087887060733 \\ ${ }^{2}$ Fakultas Ekonomi dan Bisnis Universitas Udayana (Unud), Bali, Indonesia
}

\begin{abstract}
ABSTRAK
Penelitian ini bertujuan untuk mendapatkan bukti empiris mengenai pengaruh motivasi karir, motivasi mengikuti USAP, motivasi kualitas, motivasi ekonomi, dan pengetahuan UU No. 5 Tahun 2011 tentang akuntan publik pada minat mahasiswa akuntansi mengikuti Pendidikan Profesi Akuntansi (PPAk). Responden penelitian adalah mahasiswa jurusan akuntansi program non regular angkatan 2014, Fakultas Ekonomi dan Bisnis Universitas Udayana yaitu sejumlah 185 mahasiswa. Sampel ditentukan dengan menggunakan sampel jenuh. Metode pengumpulan data adalah dengan survei. Data dianalisis dengan regresi linier berganda. Hasil analisis menunjukkan bahwa semakin tinggi motivasi karir, motivasi mengikuti USAP, motivasi kualitas, motivasi ekonomi maka semakin tinggi juga minat mengikuti PPAk, dan semakin tinggi pengetahuan mahasiswa akuntansi mengenai UU No. 5 Tahun 2011 maka semakin tinggi juga minat mahasiswa akuntansi mengikuti PPAk.

Kata kunci: motivasi, pengetahuan uu no. 5, minat mahasiswa akuntansi.
\end{abstract}

\begin{abstract}
This study aims to obtain empirical evidence on the influence of career motivation, motivation to follow USAP, quality motivation, economic motivation, and knowledge of Law no. 5 Year 2011 on public accountants on the interest of accounting students follow Accounting Profession Education (PPAk). Research respondents are students of nonregular program of class of 2014, Faculty of Economics and Business Universitas Udayana, which is 185 students. The sample is determined using a saturated sample. The method of data collection is by survey. Data were analyzed by multiple linear regression. The result of analysis shows that the higher motivation of career, motivation to follow USAP, motivation of quality, economic motivation hence higher also interest to follow PPAk, and the higher knowledge of accounting student about Law no. 5 Year 2011 hence the higher also the interest of accounting student follow PPAk.

Keywords: career, knowledge uи no. 5, accounting student interest.
\end{abstract}


Putu Ayu Bella Febryanti A. dan Ketut Alit Suardana. Pengaruh...

\section{PENDAHULUAN}

Era globalisasi seperti saat ini, semua negara dituntut untuk lebih berkembang. Termasuk juga Indonesia sebagai salah satu negara yang selalu mengikuti perkembangan zaman. Tentu saja hal tersebut berpengaruh dalam penyajian laporan keuangan. Dengan adanya kemajuan zaman seperti sekarang ini sudah pasti dituntut untuk meningkatkan akuntabilitas dan transparasi dalam setiap penyajian laporan keuangan dan hal ini merupakan bagian dari tanggungjawab akuntan publik.

Akuntan Publik dapat dikatakan elemen penting untuk mewujudkan kehidupan masyarakat yang transparan, dan perekonomian yang bebas dari kecurangan serta penipuan yang bersifat keuangan (Arifianto, 2014). Setiap tahun peminat jurusan akuntansi di berbagai universitas mengalami peningkatan sehingga lulusan setiap tahun pun menjadi semakin banyak dan persaingan dalam memperoleh pekerjaan tidak dapat dihindari lagi. Akuntansi merupakan salah satu jurusan di fakultas ekonomi yang sangat diminati oleh mahasiswa. Menurut penelitian Benny dan Yuskar (2006) menyebutkan bahwa rata-rata mahasiswa memilih jurusan akuntansi dilandasi oleh keingingan untuk menjadi professional di bidang akuntansi. Selain itu juga termotivasi dengan anggapan bahwa profesi akuntan dapat menjanjikan prospek yang cerah dan sangat dibutuhkan oleh perusahaan atau organisasi Indonesia di masa yang akan datang (Wheeler, 1983).

Pendidikan Profesi Akuntansi (PPAk) penting bagi mahasiswa jurusan akuntansi sebab PPAk dapat memberikan kontribusi untuk menjadi seorang akuntan yang profesional. Faktanya hanya sedikit dari mahasiswa lulusan 
akuntansi yang kemudian melanjutkan ke PPAk. Mengingat pentingnya PPAk bagi mahasiswa akuntansi maka diperlukan motivasi dari dalam diri mahasiswa terhadap minat untuk mengikuti PPAk, yang diharapkan dapat mencapai tujuan yang diinginkan mahasiswa tersebut.

Pemberian gelar akuntan di Indonesia awalnya didasarkan kepada UndangUndang No. 34 tahun 1954 yang menyatakan bahwa gelar akuntan diberikan kepada lulusan perguruan tinggi negeri yang ditunjuk pemerintah atau perguruan tinggi negeri dan swasta yang memenuhi syarat untuk menghasilkan akuntan atas proses pendidikannya. Hal tersebut dianggap tidak adil bagi perguruan tinggi lainnya sehingga membuat organisasi IAI (Ikatan Akuntan Indonesia) dan Kementrian Pendidikan dan Kebudayaan melalui Direktorat Jenderal Pendidikan Tinggi (DIKTI) perlu untuk melihat dan meninjau ulang peraturan tersebut. Pemerintah melalui Menteri Pendidikan kemudian mengeluarkan Surat Keputusan Menteri Pendidikan Nasional Nomor. 179/U/2001 tentang penyelenggaraan Pendidikan Profesi Akuntansi (PPAk) untuk menggantikan Undang-Undang No. 34 tahun 1954 tersebut yang menyatakan bahwa lulusan sarjana strata satu (S1) jurusan akuntansi berkesempatan menempuh Pendidikan Profesi Akuntansi di perguruan tinggi yang telah ditunjuk oleh Direktorat Jenderal Pendidikan Tinggi (DIKTI). Peraturan tersebut kemudian didukung oleh Nota Kesepahaman (MoU) yang ditandatangani oleh Ikatan Akuntan Indonesia (IAI) dengan Dirjen Dikti Kementrian Pendidikan dan Kebudayaan Nasional pada tanggal 28 Maret 2002 mengenai pengelolaan sistem dan penyelenggaraan Pendidikan Profesi Akuntansi (PPAk). 
Putu Ayu Bella Febryanti A. dan Ketut Alit Suardana. Pengaruh...

PPAk diselenggarakan di perguruan tinggi sesuai dengan persyaratan, tatacara dan kurikulum yang diatur oleh Ikatan Akuntan Indonesia (IAI) untuk menghasilkan lulusan yang menguasai keahlian bidang profesi akuntansi dan memberikan kompetensi keprofesian akuntansi (Hadiprasetyo dan Endra, 2014). Seorang sarjana lulusan akuntansi dituntut untuk lebih professional pada era globalisasi saat ini. Hal ini disebabkan adanya tuntutan dari dunia bisnis dan ekonomi yang semakin meningkat. Perkembangan profesi akuntan mempunyai hubungan erat dengan tata nilai dan budaya yang berkembang di tengah masyarakat. Hal ini mengakibatkan profesi akuntan tidak bisa lepas dari perkembangan yang terjadi di negeri ini. Profesi akuntan dituntut untuk dapat menjawab tantangan yang ditimbulkan oleh perubahan lingkungan. Konsekuensi dari adanya perubahan lingkungan dan perkembangan dunia usaha pada dasarnya menuntut peningkatan kualitas diri dari akuntan dalam memberikan jasa profesionalnya (Suprianto dan Mifkhatun, 2013).

Tujuan PPAk adalah untuk menghasilkan lulusan yang menguasai keahlian di bidang profesi akuntansi dan memberikan kompetensi keprofesian akuntansi. Mahasiswa yang telah menempuh PPAk nantinya berhak memperoleh sebutan Profesi Akuntansi (Ak). Motivasi dan minat merupakan hal yang di perlukan untuk mengetahui seberapa besar potensi mahasiswa untuk mengikuti PPAk. PPAk merupakan jenjang pendidikan tambahan yang ditujukan bagi seorang lulusan sarjana ekonomi jurusan akuntansi yang ingin mendapatkan gelar akuntan (Raminten, 2012). Indonesia saat ini masih sangat kekurangan akuntan publik. Hal ini dapat disebabkan karena kurangnya minat mahasiswa yang setelah lulus 
sarjana untuk berprofesi sebagai akuntan publik. Fakultas Ekonomi dan Bisnis Universitas Udayana dipilih sebagai lokasi penelitian dikarenakan Fakultas Ekonomi dan Bisnis Universitas Udayana merupakan satu satunya pihak penyelenggara Program Profesi akuntansi di Provinsi Bali. PPAk Fakultas Ekonomi dan Bisnis Universitas Udayana beroperasi sejak tanggal 1 April 2004 hingga sekarang dengan SK perpanjangan Ijin Nomor: 4395/D/T/K-N/2013, tanggal 30 Januari 2013.

Minat merupakan salah satu aspek psikis manusia yang dapat mendorong untuk mencapai tujuan. Seseorang yang memiliki minat terhadap suatu objek, cenderung untuk memberikan perhatian atau merasa senang yang lebih besar kepada objek tersebut. Namun apabila objek tersebut tidak menimbulkan rasa senang, maka seseorang itu tidak akan memiliki minat pada objek tersebut. Minat memiliki pengaruh yang cukup kuat dalam pencapaian prestasi pada suatu pekerjaan, jabatan atau karir. Suatu pekerjaan tentunya tidak dapat terselesaikan dengan baik apabila seseorang tidak memiliki minat untuk menyelesaikan pekerjaan tersebut. Dapat disimpulkan bahwa seseorang yang berminat terhadap suatu aktivitas akan memperhatikan aktivitas itu secara konsisten dengan rasa senang dikarenakan hal tersebut datang dari dalam diri seseorang yang didasarkan rasa suka dan tidak adanya paksaan dari pihak luar. Slameto (2010:180) menyatakan bahwa minat adalah suatu rasa lebih suka dan rasa ketertarikan pada suatu hal atau aktivitas, tanpa ada yang menyuruh.

Teori tindakan beralasan (Theory of Reasoned Action/TRA) adalah sebuah teori keprilakuan yang dikemukakan oleh Ajzen dan Fishbein 1991, untuk 
Putu Ayu Bella Febryanti A. dan Ketut Alit Suardana. Pengaruh...

selanjutnya disingkat TRA. Teori ini dikembangkan menggunakan pendekatan kognitif, dengan ide dasar bahwa : "...humans are reasonable animals who dicliding what actions to take, systematically process and utilized informations available to them" (Ajzen dan Fishbein dalam Smet 1991:164). Spesifikasi TRA dibanding dengan teori keperilakuan lainnya adalah menghubungkan kepercayaan/keyakinan (beliefs), sikap (attitude), minat atau kehendak atau keinginan (intention) dan perilaku (behavior). Minat dipandang sebagai predictor terbaik dari perilaku, jika ingin mengetahui apa yang ingin dilakukan seseorang, cara terbaik memprediksinya adalah dengan mengetahui minat orang tersebut. Oleh karenanya, TRA juga disebut sebagai behavioral intention theory, yaitu teori yang menjelaskan bahwa minat seseorang untuk melakukan atau tidak melakukan suatu perilaku atau tindakan merupakan penentu langsung dari perilaku atau tindakannya. (Jogiyanto, 2007:31). Perluasan dari Theory Reasoned Action (TRA) adalah Theory of Planned Behavior (TPB).

Theory of Planned Behavior (TPB) merupakan suatu teori yang memprediksi perilaku individu yang disengaja, karena perilaku bisa dipertimbangkan dan direncanakan. TPB didasarkan pada asumsi bahwa manusia adalah makhluk yang rasional dan menggunakan informasi-informasi yang mungkin baginya, secara sistematis. Individu memikirkan implikasi dari tindakannya sebelum memutuskan untuk melakukan atau tidak melakukan perilaku-perilaku tertentu. Menurut Theory Planned Behavior, selain faktor-faktor utama yaitu sikap, norma subjektif dan kontrol perilaku persepsian, banyak variabel yang mungkin berhubungan atau mempengaruhi kepercayaan yang 
seseorang seperti: umur, jenis kelamin, etnis,status sosial ekonomi, pendidikan, kebangsaan, agama, keanggotaan, kepribadian, suasana hati, emosi, sikap dan nilai secara umum, intelegensi, anggota kelompok tertentu, pengalaman masa lalu, paparan informasi, dukungan sosial, dan sebagainya. Minat mengikuti Pendidikan Profesi Akuntansi dapat dipengaruhi oleh beberapa faktor. Faktor itu antara lain motivasi karir, motivasi ekonomi, mencari ilmu, mengikuti USAP, lama pendidikan (Riani, 2008). Secara umum orang yang berminat mengikuti Pendidikan Profesi Akuntansi memiliki motivasi.

Motivasi merupakan hal yang melatarbelakangi individu berbuat untuk mencapai tujuan tertentu (Dyastari dan Yadnyana, 2016). Penelitian Hadiprasetyo dan Endra (2014) menunjukkan hasil bahwa motivasi berpengaruh positif pada minat mahasiswa akuntansi Fakultas Ekonomi Universitas Negeri Yogyakarta (UNY) untuk mengikuti PPAk. Hasil penelitian tersebut sejalan dengan penelitian Aryani dan Adi (2016) yang meneliti tentang pengaruh motivasi diantaranya motivasi kualitas, karir, dan ekonomi pada minat mahasiswa mengikuti PPAk yang menunjukkan hasil bahwa motivasi kualitas, karir dan ekonomi berpengaruh positif pada minat mahasiswa mengikuti PPAk, berarti mahasiswa mengetahui dengan benar apa yang menjadi target dan tujuan yang diinginkan.

Karir adalah hal yang dapat memotivasi individu untuk melakukan usahausaha yang dinilai dapat meningkatkan kinerja, sehingga dapat membawanya ke jenjang karir yang lebih baik lagi. Motivasi karir merupakan dorongan yang timbul dalam diri seseorang untuk meningkatkan kemampuan pribadinya dalam 
Putu Ayu Bella Febryanti A. dan Ketut Alit Suardana. Pengaruh...

rangka mencapai kedudukan, jabatan, atau karir yang lebih baik dari sebelumnya (Rahardian, 2008).

Siegel et al. (1991) mengungkapkan bahwa auditor yang memiliki dasar pendidikan akuntan yang professional perlu waktu yang lebih pendek untuk dipromosikan sebagai auditor senior atau manajer. Pada teori kebutuhan McClelland menyatakan bahwa salah satu dari tingkat kebutuhan manusia adalah kebutuhan untuk kekuasaan (Robbins, 2008). Tengker dan Marosa (2007) menyatakan bahwa seseorang akan termotivasi untuk meningkatkan karirnya karena berpendapat bahwa karir yang lebih yang lebih tinggi akan dapat meningkatkan social status ekonomi dan mencapai kepuasan diri.

Institusi pendidikan mempunyai pengaruh besar terhadap perkembangan karir seorang akuntan. Siegel, Blank, dan Rigsby (1991) dalam Samiaji (2004) melakukan penelitian untuk mengetahui hubungan antara struktur organisasi institusi pendidikan akuntansi dengan perkembangan professional selanjutnya bagi para auditor. Auditor yang mempunyai latar belakang pendidikan yang professional dalam bidang akuntansi membutuhkan waktu yang lebih sedikit untuk dipromosikan menjadi auditor senior dan manajer. Sebagai sebuah pendidikan profesi PPAk dapat memberikan kontribusi positif untuk mahasiswa yang ingin mengembangkan kemampuan dan keahliannya di bidang akuntansi. Jadi seseorang yang ingin memiliki motivasi karir yang tinggi dapat meningkatkan minatnya untuk mengikuti PPAk, karena dengan mengikuti diharapkan dapat membantu karirnya di masa depan. Karir juga dipandang sebagai rangkaian promosi untuk memperoleh pekerjaan yang mempunyai beban 
pertanggungjawaban lebih tinggi atau penempatan posisi yang lebih baik dengan tujuan agar mereka memiliki kehidupan karir yang memuaskan (Kermis, 2011).

Penelitian yang dilakukan oleh Farmer (1976), Nisa (2012), Rita dan Indiarto (2013), dan Yudhistira (2014) menunjukkan bahwa motivasi karir berpengaruh positif terhadap minat mahasiswa akuntansi untuk mengikuti PPAk. Dari penjelasan tersebut dapat disimpulkan bahwa motivasi karir adalah dorongan yang timbul dalam diri seseorang untuk meningkatkan kemampuan pribadinya dalam rangka mencapai kedudukan, jabatan atau karir yang lebih baik dari sebelumnya. Berdasarkan uraian diatas, maka dapat diajukan hipotesis sebagai berikut:

$\mathrm{H}_{1}$ : Semakin kuat keinginan seseorang untuk meniti karir maka semakin berminat seseorang tersebut untuk mengikuti PPAk

Ujian Sertfikasi Akuntan Publik (USAP) pertama diselenggarakan pada tahun 1997, Indonesia telah mempunyai suatu ujian profesi sebagai suatu sistem saringan yang baku bagi mereka yang akan berpraktik sebagai Akuntan Publik. Pemerintah mengeluarkan suatu ketentuan yang antara lain mensyaratkan bagi calon Akuntan Publik untuk lulus dari Ujian Sertifikasi Akuntan Publik (USAP). Ujian Sertfikasi Akuntan Publik (USAP) merupakan suatu ujian profesi yang berfungsi sebagai sistem penyaring yang baku bagi yang akan berpraktik sebagai sistem penyaring yang baku bagi mereka yang akan berpraktik sebagai akuntan publik. Departemen Keuangan selaku Pembina profesi Akuntan Publik di Indonesia telah mengeluarkan ketentuan yang antara lain mensyaratkan bagi calon Akuntan Publik untuk lulus dari Ujian Sertifikasi Akuntan Publik (USAP). USAP hanya dapat diikuti oleh mereka yang memiliki gelar atau sebutan akuntan yang 
Putu Ayu Bella Febryanti A. dan Ketut Alit Suardana. Pengaruh...

dibuktikan dengan memiliki Nomor Register Akuntan sesuai dengan peraturan atau ketentuan perundang-undangan yang berlaku atau mereka yang telah mengikuti USAP tetapi belum lulus seluruh mata ujian. Namun, nomor register akuntan hanya dapat diperoleh lulusan dari PPAk. Jadi, untuk peserta USAP diharuskan telah mengikuti PPAk terlebih dahulu.

$\mathrm{H}_{2}$ : Semakin kuat keinginan seseorang untuk mengikuti Ujian Sertfikasi Akuntan Publik (USAP) maka semakin berminat seseorang tersebut untuk mengikuti PPAk.

Motivasi kualitas adalah dorongan yang timbul di dalam diri seseorang untuk memiliki dan meningkatkan kualitas diri dan kemampuannya dalam bidang yang ditekuninya sehingga bisa melaksanakan tugas dengan baik dan benar (Widyastuti,dkk, 2004). Pendidikan profesi akuntansi penting bagi mahasiswa yang telah lulus sebab PPAk dapat memberikan kontribusi utnuk menjadi seorang akuntan yang professional.

Elemen kualitas dan kompensasi merupakan hal yang sangat diperhatikan dalam profesi akuntansi, khususnya profesi akuntan publik, bahkan elemen ini dimasukkan dalam standar audit (Rahardian, 2008). Standar umum auditing yang pertama menyatakan bahwa audit harus dilaksanakan oleh seorang atau lebih yang memiliki keahlian dan pelatihan teknis yang cukup sebagai seorang auditor. Sehingga seorang auditor juga harus menguasai ilmu pengetahuan lain seperti ekonomi perusahaan, sistem informasi akuntansi, manajemen perusahaan, pemasaran, hukum dagang, hukum pajak, akuntansi biaya, dan bahasa inggris. Elemen kualitas atau kompetensi adalah hal yang sangat diperhatikan di dalam profesi akuntansi. Bahkan elemen ini dimasukkan dalam Standar Audit.Dalam 
melaksanakan audit, auditor harus benar-benar memiliki keahlian dan bertindak sebagai seorang ahli dalam bidang auditing. PPAk dapat meningkatkan kualitas seorang lulusan Sarjana dalam bidang akuntansi yang ingin bekerja di bidang akuntansi.

Motivasi adalah suatu kondisi yang menyebabkan perilaku tertentu, dan yang memberi arah dan ketahanan (persistence) pada tingkah laku tersebut (Wlodkowski, 1981). Motivasi kualitas adalah dorongan yang timbuk dari dalam diri seseorang untuk memiliki dan meningkatkan kualitas atau kemampuan dalam melaksanakan tugas dengan baik dan benar (Fahrani, 2012). Penelitian Kusumastuti dan Indarto (2013) mengenai motivasi kualitas menunjukkan bahwa motivasi kualitas berpengaruh positif pada minat mahasiswa akuntansi untuk mengikuti PPAk. Hasil penelitian tersebut sejalan dengan penelitian Aryani dan Erawati (2016) yang menunjukkan bahwa motivasi kualitas berpengaruh positif pada minat untuk mengikuti PPAk.

$\mathrm{H}_{3}$ : Semakin kuat keinginan seseorang untuk meningkatkan kualitas, maka semakin berminat seseorang tersebut untuk mengikuti PPAk

Motivasi ekonomi dapat diartikan sebagai suatu dorongan yang timbul dari dalam diri seseorang untuk meningkatkan kemampuan pribadinya dalam rangka mencapai penghargaan finansial dan kemampuan ekonominya. Teori McClelland menunjukan bahwa setiap individu memiliki keinginan untuk mengendalikan lingkungannya atau kebutuhan kekuasaan, termasuk kekuasaan keuangan (Moorhead dan Griffin, 2014). Paisey (2006) yang meneliti dampak dari implementasi kebijakan yang terkait dengan pendidikan profesi akuntansi 
Putu Ayu Bella Febryanti A. dan Ketut Alit Suardana. Pengaruh...

menunjukan bahwa pendidikan dapat dipengaruhi oleh beberapa faktor, salah satunya adalah faktor ekonomi.

Hal ini didukung oleh penelitian yang dilakukan oleh Kusumastuti dan Indarto (2013) yang menyatakan bahwa motivasi ekonomi berpengaruh positif dan signifikan pada minat mahasiswa akuntansi mengikuti PPAk. Aryani dan Adi (2016) menyatakan motivasi ekonomi berpengaruh positif pada minat mahasiswa mengikuti PPAk. Berdasarkan pemaparan di atas dapat disimpulkan bahwa semakin kuat pengaruh motivasi ekonomi maka semakin tinggi minat mahasiswa akuntansi mengikuti pendidikan profesi akuntansi, maka dapat dirumuskan hipotesis sebagai berikut

$\mathrm{H}_{4}$ : Semakin kuat keinginan seseorang untuk meningkatkan taraf kemampuan finansial yang ingin dicapai, maka semakin berminat seseorang tersebut untuk mengikuti PPAk

Pengetahuan adalah segala sesuatu yang diperoleh seseorang melalui indra yang dimilikinya (Kamus Besar Bahasa Indonesia, 2016). Pengetahuan pada umumnya diperoleh dari pengalaman yang dimiliki atau diperoleh dari informasi yang disampaikan oleh seseorang maupun media tertentu.

UU No. 5 Tahun 2011 merupakan peraturan yang mengatur tentang akuntan publik. Pengetahuan undang-undang tentang akuntan publik disini meliputi aturan-aturan apa saja yang berlaku untuk akuntan publik, persyaratan menjadi akuntan publik bahkan risiko menjadi akuntan publik, maka kemungkinan orang tersebut memiliki minat untuk menempuh pendidikan profesi akuntansi, karena hal itulah yang merupakan syarat untuk menjadi seorang akuntan publik (Kusumastuti dan Indarto, 2013). Penelitian Kusumastuti dan Indarto (2013) dan 
Sherlynda (2016) menunjukkan bahwa pengetahuan mahasiswa jurusan akuntansi tentang UU No. 5 Tahun 2011 berpengaruh positif pada minat mahasiswa akuntansi mengikuti PPAk.

$\mathrm{H}_{5}$ : Semakin kuat keinginan seseorang untuk memahami pengetahuan UU No. 5 Tahun 2011 tentang akuntan publik, maka semakin berminat seseorang tersebut untuk mengikuti PPAk.

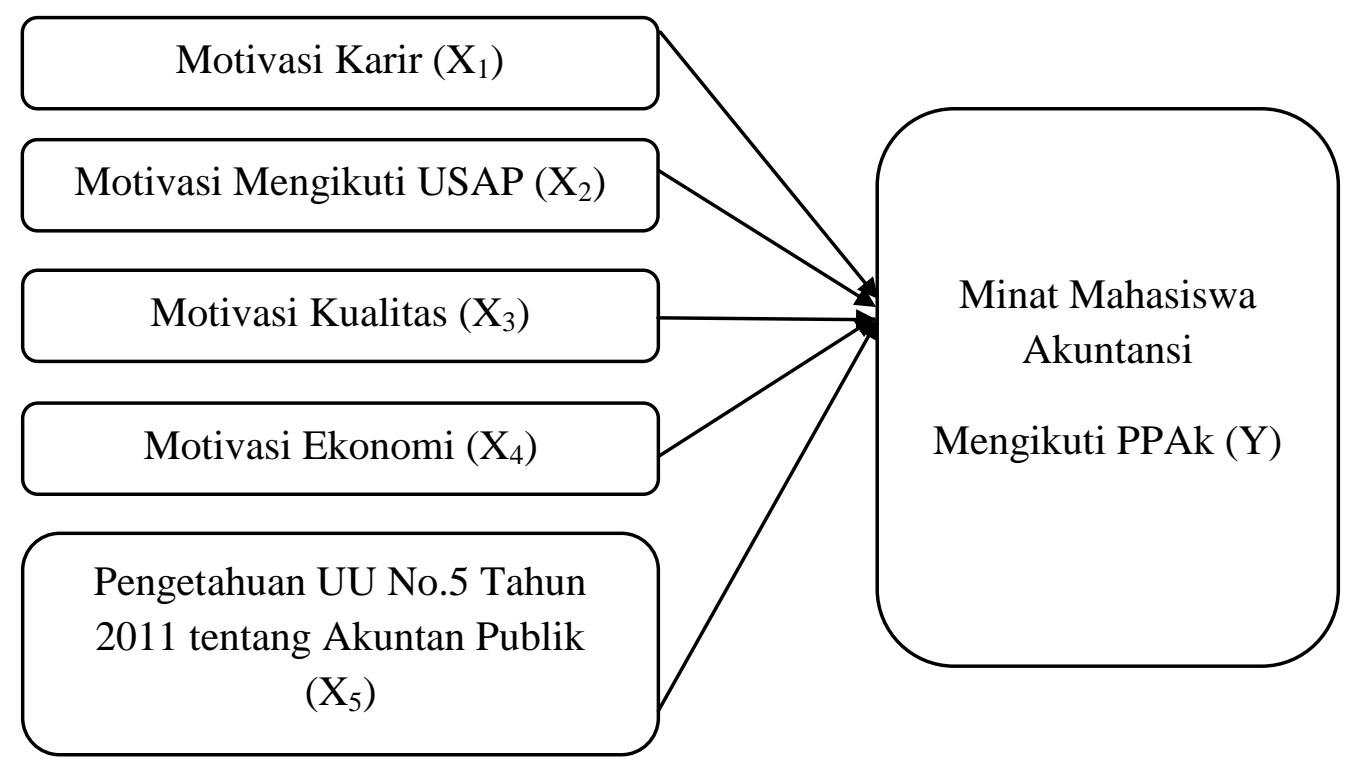

\section{Gambar 1. Desain Penelitian}

\section{METODE PENELITIAN}

Penelitian ini menggunakan pendekatan kuantitatif berbentuk asosiatif tipe kausalitas. Pendekatan kuantitatif adalah metode penelitian yang digunakan untuk meneliti populasi atau sampel tertentu yang bertujuan untuk menguji hipotesis yang telah ditetapkan (Sugiyono, 2017:23). Penelitian asosiatif tipe kausalitas adalah penelitian yang bertujuan untuk mengetahui hubungan sebab akibat antara dua variabel atau lebih (Sugiyono, 2017:38).

Lokasi penelitian dilakukan pada mahasiswa jurusan akuntansi program non reguler angkatan 2014, Fakultas Ekonomi dan Bisnis, Universitas Udayana yang 
Putu Ayu Bella Febryanti A. dan Ketut Alit Suardana. Pengaruh...

beralamat di Jalan P.B Sudirman, Denpasar. Alasan yang mendasari dipilihnya lokasi ini karena penelitian ini merupakan studi empiris pada mahasiswa jurusan akuntansi program non reguler angkatan 2014 yang segala aktivitasnya dilaksanakan di Kampus Sudirman, Fakultas Ekonomi dan Bisnis, Universitas Udayana. Sedangkan obyek dalam penelitian adalah minat mahasiswa jurusan akuntansi mengikuti PPAk yang dijelaskan dengan motivasi karir, motivasi mengikuti USAP, motivasi kualitas, motivasi ekonomi, dan pengetahuan UU No.5 Tahun 2011 yang dimiliki mahasiswa jurusan akuntansi program non reguler angkatan 2014 Fakultas Ekonomi dan Bisnis, Universitas Udayana.

Variabel terikat dalam penelitian ini adalah minat mahasiswa akuntansi mengikuti PPAk (Y). Sedangkan variabel bebas dalam penelitian ini adalah motivasi karir $\left(\mathrm{X}_{1}\right)$, motivasi mengikuti $\operatorname{USAP}\left(\mathrm{X}_{2}\right)$, motivasi kualitas $\left(\mathrm{X}_{3}\right)$, motivasi ekonomi $\left(\mathrm{X}_{4}\right)$, pengetahuan UU No.5 Tahun 2011 tentang akuntan publik $\left(\mathrm{X}_{5}\right)$.

Jenis data yang digunakan dalam penelitian ini adalah data kuantitatif berupa skor atau jawaban dari pernyataan-pernyataan yang terdapat dalam kuesioner. Data kualitatif dalam penelitian ini berupa nama-nama mahasiswa akuntansi program non regular angkatan 2014, indikator-indikator yang terdapat dalam kuesioner. Sedangkan sumber data yang digunakan dalam penelitian ini adalah sumber primer berupa jawaban dari responden atas instrumen pernyataan kuesioner yang disebarkan. Sumber sekunder dalam penelitian ini berupa informasi yang diperoleh dari program PPAk Universitas Udayana. 
Populasi dalam penelitian ini adalah seluruh mahasiswa jurusan akuntansi program non reguler Fakultas Ekonomi dan Bisnis Universitas Udayana angkatan 2014, yakni sejumlah 185 mahasiswa. Alasan pemilihan mahasiswa angkatan 2014 adalah mahasiswa pada tingkat ini telah memasuki semester 7 yang merupakan tahun terakhir dalam perkuliahan dan tentunya telah memiliki rencana ke depan akan melanjutkan kemana setelah menyelesaikan program S1 serta diharapkan mahasiswa pada tingkat ini telah memiliki gambaran atau pengetahuan mengenai profesi seorang akuntan publik. Metode penentuan sampel yang dipilih non probability sampling dengan teknik sampling jenuh. Sampling jenuh adalah teknik penentuan sampel bila semua anggota populasi digunakan sebagai sampel (Sugiyono, 2017:85).

Metode pengumpulan data yang digunakan dalam penelitian ini adalah dengan survei atau menggunakan kuesioner. Kuesioner diberikan pada responden secara langsung dan melalui media internet agar lebih efisien jika responden tidak bisa ditemui secara langsung karena kondisi tertentu. Kuesioner ini terdiri atas pernyataan mengenai pengaruh motivasi (motivasi karir, motivasi mengikuti USAP, motivasi kualitas, motivasi ekonomi), dan pengetahuan UU No.5 Tahun 2011 tentang akuntan publik pada minat mahasiswa akuntansi mengikuti PPAk.

Teknik analisis data yang digunakan dalam penelitian ini adalah teknik analisis regresi linier berganda Sebelum melakukan pengujian regresi, terdapat beberapa asumsi yang harus dipenuhi agar data yang akan dimasukkan dalam model regresi telah memenuhi ketentuan dan syarat dalam regresi. Uji asumsi 
Putu Ayu Bella Febryanti A. dan Ketut Alit Suardana. Pengaruh...

klasik dalam penelitian ini mencakup uji normalitas, multikolinearitas, dan heteroskedastisitas. Model regresi linier berganda dirumuskan sebagai berikut.

$\mathrm{Y}=\alpha+\beta_{1} \mathrm{X}_{1}+\beta_{2} \mathrm{X}_{2}+\beta_{3} \mathrm{X}_{3}+\beta_{4} \mathrm{X}_{4}+\beta_{5} \mathrm{X}_{5}+\mathrm{e}$

Keterangan:

$\mathrm{Y}=$ Minat mengikuti PPAk

$\mathrm{A}=$ Konstanta

$\beta_{1}=$ Angka arah atau koefisien regresi motivasi karir

$\beta_{2}=$ Koefisien regresi motivasi mengikuti USAP

$\beta_{3}=$ Koefisien regresi motivasi kualitas

$\beta_{4}=$ Koefisien regresi motivasi ekonomi

$\beta_{5}=$ Koefisien regresi Pengetahuan UU No.5 Tahun 2011 Tentang Akuntan Publik Tahun 2011

$\mathrm{X}_{1}=$ Motivasi karir

$\mathrm{X}_{2}=$ Motivasi mengikuti USAP

$\mathrm{X}_{3}=$ Motivasi Kualitas

$\mathrm{X}_{4}=$ Motivasi Ekonomi

$\mathrm{X}_{5}=$ Pengetahuan UU No.5 Tahun 2011 Tentang Akuntan Publik

e $=$ Standar eror

\section{HASIL DAN PEMBAHASAN}

Karakteristik responden yang diteliti dalam penelitian ini meliputi jenis kelamin dan usia. Ringkasan karakteristik responden dapat dilihat pada Tabel 1. Berdasarkan jenis kelamin dapat dilihat bahwa responden dalam penelitian ini adalah responden laki-laki dengan jumlah 56 orang $(49,55 \%)$ dan responden perempuan berjumlah 57 orang $(50,44 \%)$. Berdasarkan usia dapat dilihat bahwa responden yang berusia 20 tahun sebanyak 2 orang $(1,77 \%)$, responden yang berusia 21 tahun sebanyak 35 orang (30,98\%), responden yang berusia 22 tahun sebanyak 54 orang $(47,78 \%)$ dan responden yang berusia 23 tahun sebanyak 22 orang $(19,47 \%)$. 
Tabel 1.

Karakteristik Responden

\begin{tabular}{ccccc}
\hline No. & Karakteristik & Klasifikasi & Jumlah (orang) & Presentase (\%) \\
\hline 1 & & Laki-laki & 56 & $49,55 \%$ \\
& \multirow{2}{*}{ Jenis Kelamin } & 57 & $50,44 \%$ \\
& Jumlah & & $\mathbf{1 1 3}$ & $\mathbf{1 0 0}$ \\
\hline \multirow{2}{*}{ Usia } & 20 Tahun & 21 Tahun & 35 & $1,77 \%$ \\
& 22 Tahun & 54 & $30.98 \%$ \\
& & 23 Tahun & 22 & $47,78 \%$ \\
& & & $\mathbf{1 1 3}$ & $\mathbf{1 0 0}$ \\
\hline
\end{tabular}

Sumber: Data diolah, 2018

Suatu instrumen yang valid ditunjukkan dengan r Pearson Correlation $\geq$ 0,30. Pada Tabel 2. menunjukkan bahwa seluruh variabel memiliki nilai koefisien korelasi dengan skor total seluruh item pernyataan lebih besar dari 0,30 . Hal ini menunjukkan butir-butir pernyataan dalam instrumen penelitian tersebut valid.

Tabel 2. Hasil Uji Validitas

\begin{tabular}{|c|c|c|c|c|}
\hline No & Variabel & $\begin{array}{c}\text { Item } \\
\text { Pernyataan } \\
\end{array}$ & $\begin{array}{c}\text { Korelasi } \\
\text { Item Total } \\
\end{array}$ & Keterangan \\
\hline \multirow{10}{*}{1} & \multirow{10}{*}{ Motivasi Karir $\left(\mathrm{X}_{1}\right)$} & $\mathrm{X} 1.1$ & 0,369 & Valid \\
\hline & & $\mathrm{X} 1.2$ & 0,503 & Valid \\
\hline & & $\mathrm{X} 1.3$ & 0,751 & Valid \\
\hline & & $\mathrm{X} 1.4$ & 0,557 & Valid \\
\hline & & $\mathrm{X} 1.5$ & 0,472 & Valid \\
\hline & & $\mathrm{X} 1.6$ & 0,451 & Valid \\
\hline & & $\mathrm{X} 1.7$ & 0,449 & Valid \\
\hline & & $\mathrm{X} 1.8$ & 0,767 & Valid \\
\hline & & $\mathrm{X} 1.9$ & 0,492 & Valid \\
\hline & & $\mathrm{X} 1.10$ & 0,832 & Valid \\
\hline \multirow{3}{*}{2} & \multirow{3}{*}{$\begin{array}{l}\text { Motivasi Mengikuti USAP } \\
\qquad\left(\mathrm{X}_{2}\right)\end{array}$} & $\mathrm{X} 2.1$ & 0,775 & Valid \\
\hline & & $\mathrm{X} 2.2$ & 0,881 & Valid \\
\hline & & $\mathrm{X} 2.3$ & 0,775 & Valid \\
\hline \multirow{5}{*}{3} & \multirow{5}{*}{ Motivasi Kualitas $\left(\mathrm{X}_{3}\right)$} & X3.1 & 0,734 & Valid \\
\hline & & X3.2 & 0,657 & Valid \\
\hline & & $\mathrm{X} 3.3$ & 0,608 & Valid \\
\hline & & X3.4 & 0,665 & Valid \\
\hline & & X3.5 & 0,623 & Valid \\
\hline
\end{tabular}


Putu Ayu Bella Febryanti A. dan Ketut Alit Suardana. Pengaruh...

\begin{tabular}{|c|c|c|c|c|}
\hline \multirow{6}{*}{4} & \multirow{6}{*}{ Motivasi Ekonomi $\left(\mathrm{X}_{4}\right)$} & $\mathrm{X} 4.1$ & 0,842 & Valid \\
\hline & & $\mathrm{X} 4.2$ & 0,768 & Valid \\
\hline & & $\mathrm{X} 4.3$ & 0,642 & Valid \\
\hline & & $\mathrm{X} 4.4$ & 0,690 & Valid \\
\hline & & $\mathrm{X} 4.5$ & 0,607 & Valid \\
\hline & & X4.6 & 0,842 & Valid \\
\hline \multirow{12}{*}{5} & \multirow{12}{*}{$\begin{array}{l}\text { Pengetahuan Undang- } \\
\text { Undang Tentang Akuntan } \\
\text { Publik }\left(\mathrm{X}_{5}\right)\end{array}$} & $\mathrm{X} 5.1$ & 0,502 & Valid \\
\hline & & X5.2 & 0,514 & Valid \\
\hline & & $\mathrm{X} 5.3$ & 0,525 & Valid \\
\hline & & X5.4 & 0,496 & Valid \\
\hline & & X5.5 & 0,400 & Valid \\
\hline & & X5.6 & 0,543 & Valid \\
\hline & & X5.7 & 0,370 & Valid \\
\hline & & X5.8 & 0,560 & Valid \\
\hline & & X5.9 & 0,567 & Valid \\
\hline & & $\mathrm{X} 5.10$ & 0,443 & Valid \\
\hline & & $\mathrm{X} 5.11$ & 0.489 & Valid \\
\hline & & $\mathrm{X} 5.12$ & 0,380 & Valid \\
\hline \multirow{5}{*}{6} & \multirow{5}{*}{$\begin{array}{l}\text { Minat Mahasiswa } \\
\text { Akuntansi Mengikuti } \\
\text { PPAk (Y) }\end{array}$} & X6.1 & 0,608 & Valid \\
\hline & & X6.2 & 0,825 & Valid \\
\hline & & X6.3 & 0,768 & Valid \\
\hline & & X6.4 & 0,775 & Valid \\
\hline & & X6.5 & 0,808 & Valid \\
\hline
\end{tabular}

Sumber: Data diolah, 2018

Uji reliabilitas mampu menunjukan sejauh mana instrument dapat dipercaya dan diharapkan. Nilai suatu instrument dikatakan reliable apabila nilai Alpha Cronbach $\geq 0,60$. Hasil uji reliabilitas dapat dilihat pada Tabel 3 .

Tabel 3.

Hasil Uji Reliabilitas

\begin{tabular}{clcc}
\hline No. & \multicolumn{1}{c}{ Variabel } & Cronbach's Alpha & Keterangan \\
\hline $\mathbf{1}$ & Motivasi Karir (X1) & 0,769 & Reliabel \\
$\mathbf{2}$ & Motivasi Mengikuti USAP (X2) & 0,739 & Reliabel \\
$\mathbf{3}$ & Motivasi Kualitas (X3) & 0,865 & Reliabel \\
$\mathbf{4}$ & Motivasi Ekonomi (X4) & 0,819 & Reliabel \\
$\mathbf{5}$ & Pengetahuan UU No.5 Tahun 2011 (X5) & 0,752 & Reliabel \\
$\mathbf{6}$ & Minat Mahasiswa Akuntansi Mengikuti PPAk (Y) & 0,813 & Reliabel \\
\hline \multicolumn{2}{l}{ Sumber: Data diolah, 2018 } & &
\end{tabular}


Berdasarkan Tabel 3. menunjukkan bahwa nilai Cronbach's Alpha masingmasing variabel lebih besar dari 0,60 yang artinya bahwa seluruh pernyataan dalam kuesioner penelitian ini reliabel dan dapat digunakan.

Uji normalitas menggunakan uji Kolmogorov-Smirnov, dengan uji ini dapat diketahui data yang digunakan berdistribusi normal atau tidak. Apabila Sign t hitung $>0.05$, maka data tersebut berdistribusi normal dan begitu juga sebaliknya (Santoso, 2001).

Tabel 4.

Hasil Uji Normalitas

\begin{tabular}{lc}
\hline \multicolumn{1}{c}{ Keterangan } & Unstandardized Residual \\
\hline $\mathrm{N}$ & 113 \\
asymp.sig (2-tailed) & 0,476 \\
\hline Sumber: Data diolah, 2018 &
\end{tabular}

Hasil Pengujian Kolmogrov-Smirnov pada Tabel 4. menunjukkan bahwa nilai signifikansi untuk persamaan model regresi adalah $0,476>0,05$. Hal ini menunjukkan bahwa persamaan regresi dalam model penelitian ini memiliki sebaran data yang normal.

Uji multikolinieritas digunakan untuk mengetahui apakah antara variabel bebas terjadi multikolinieritas atau tidak. Uji yang digunakan yaitu dengan melihat nilai VIF (Varian Inflation Factor) dan Tolerance pada proses regresi biasa, jika keduanya mendekati 1 atau besaran VIF kurang dari 10 maka model tidak terkena multikolinieritas. Berdasasrkan hasil pengujian multikolinearitas dapat diperoleh hasil sebagai berikut. 
Tabel 5.

Hasil Uji Multikolinearitas

\begin{tabular}{|c|c|c|}
\hline \multirow{2}{*}{ Variabel } & \multicolumn{2}{|c|}{ Collinearity Statistic } \\
\hline & Tolerance & VIF \\
\hline Motivasi Karir (X1) & 0,982 & 1,018 \\
\hline Motivasi Mengikuti USAP (X2) & 0,977 & 1,023 \\
\hline Motivasi Kualitas (X3) & 0,874 & 1,144 \\
\hline Motivasi Ekonomi (X4) & 0,827 & 1,209 \\
\hline Pengetahuan UU No.5 Tahun 2011 (X5) & 0,916 & 1,091 \\
\hline
\end{tabular}

Hasil regresi pada Tabel 5. menunjukkan bahwa nilai tolerance pada masing-masing variabel lebih besar dari $10 \%(0,1)$, demikian pula dengan nilai VIF masing-masing variabel yang lebih kecil dari 10. Dengan demikian dapat disimpulkan antara variabel bebas dalam penelitian ini tidak terjadi multikolinearitas.

Uji Heteroskedastisitas bertujuan untuk menguji apakah dalam model terjadi ketidaksamaan varian atau residual satu pengamatan ke pengamatan lainnya. Jika tingkat signifikan lebih besar dari 0,05 maka terjadi heteroskedastisitas.

\section{Tabel 6.}

Hasil Uji Heterokedastisitas

\begin{tabular}{lll}
\hline Variabel & Sig. & Keterangan \\
\cline { 2 - 3 } Motivasi Karir (X1) & 0,097 & Bebas Heterokedastisitas \\
Motivasi Mengikuti USAP (X2) & 0,772 & Bebas Heterokedastisitas \\
Motivasi Kualitas (X3) & 0,124 & Bebas Heterokedastisitas \\
Motivasi Ekonomi (X4) & 0,636 & Bebas Heterokedastisitas \\
Pengetahuan UU No.5 Tahun 2011 (X5) & 0,094 & Bebas Heterokedastisitas \\
\hline
\end{tabular}

Sumber: Data diolah, 2018

Tabel 6. menunjukkan bahwa seluruh variabel memiliki nilai signifikan lebih besar dari 0,05 sehingga model regresi pada penelitian ini tidak mengandung gejala heteroskedastisitas. 
Sesuai dengan hasil perhitungan dengan menggunakan program SPSS for windows maka diperoleh hasil analisis regresi linear berganda. Dari Tabel 7. dapat disusun persamaan regresi linear berganda yaitu:

$Y=5,932+0,413 X_{1}+0,296 X_{2}+0,192 X_{3}+0,259 X_{4}+0,254 X_{5}+e$

Nilai konstanta sebesar 5,932 berarti apabila motivasi karir $\left(\mathrm{X}_{1}\right)$, motivasi mengikuti USAP $\left(\mathrm{X}_{2}\right)$, motivasi kualitas $\left(\mathrm{X}_{3}\right)$, motivasi ekonomi $\left(\mathrm{X}_{4}\right)$, pengetahuan UU No.5 tahun $2011\left(\mathrm{X}_{5}\right)$ sama dengan nol, maka minat mahasiswa akuntansi mengikuti PPAk (Y) sebesar 5,932.

Tabel 7.

Hasil Analisis Regresi Linear Berganda

\begin{tabular}{|c|c|c|c|c|c|}
\hline \multirow[t]{2}{*}{ Variabel } & \multicolumn{2}{|c|}{$\begin{array}{l}\text { Unstandardized } \\
\text { Coefficients }\end{array}$} & \multirow{2}{*}{$\begin{array}{c}\begin{array}{c}\text { Standardized } \\
\text { Coefficients }\end{array} \\
\text { Beta }\end{array}$} & \multirow[t]{2}{*}{$\mathbf{T}$} & \multirow[t]{2}{*}{ Sig } \\
\hline & $\mathbf{B}$ & Std. Eror & & & \\
\hline (Constant) & 5,932 & 3,224 & & 1,840 & 0,075 \\
\hline Motivasi Karir (X1) & 0,413 & 0,149 & 0,308 & 2,774 & 0,009 \\
\hline Motivasi Mengikuti USAP (X2) & 0,296 & 0,103 & 0,383 & 2,872 & 0,007 \\
\hline Motivasi Kualitas (X3) & 0,192 & 0,073 & 0,342 & 2,606 & 0,014 \\
\hline Motivasi Ekonomi (X4) & 0,259 & 0,109 & 0,276 & 2,378 & 0,023 \\
\hline $\begin{array}{l}\text { Pengetahuan UU No.5 Tahun } \\
2011 \text { (X5) }\end{array}$ & 0,254 & 0,092 & 0.320 & 2,767 & 0,009 \\
\hline Adjust $R^{2}$ & & & & & 0,554 \\
\hline $\mathrm{R}^{2}$ & & & & & 0,513 \\
\hline $\mathrm{F}$ & & & & & 14,887 \\
\hline Sig. F & & & & & 0,002 \\
\hline
\end{tabular}

Berdasarkan Tabel 7. menunjukkan bahwa koefisien determinasi yaitu nilai adjusted $R^{2}$ adalah 0,554 atau 55,4 persen, artinya sebesar 55,4 persen variasi minat mengikuti PPAk dipengaruhi oleh motivasi karir, motivasi mengikuti USAP, motivasi kualitas, motivasi ekonomi, pengetahuan UU No.5 Tahun 2011. 
Putu Ayu Bella Febryanti A. dan Ketut Alit Suardana. Pengaruh...

Sedangkan sisanya sebesar 44,6 persen dijelaskan oleh faktor lain yang tidak dimasukkan dalam model penelitian ini.

Uji kelayakan model bertujuan untuk mengetahui apakah model regresi yang digunakan dalam penelitian ini layak atau tidak digunakan sebagai alat analisis untuk menguji pengaruh variabel bebas pada variabel terikatnya. Berdasarkan output SPSS nilai dari F hitung 14,887 (lebih besar dari F tabel) dengan nilai signifikansi 0,002 (kurang dari 0,05) maka dapat disimpulkan bahwa terdapat pengaruh yang signifikan antara motivasi karir, motivasi mengikuti USAP, motivasi kualitas, motivasi ekonomi, dan pengetahuan UU No. 5 tahun 2011 pada minat mahasiswa akuntansi mengikuti PPAk, sehingga model penelitian dikatakan layak untuk digunakan sebagai model regresi.

Uji hipotesis bertujuan untuk mengetahui apakah masing-masing variabel independen mempunyai pengaruh secara signifikan pada variabel dependennya. Level of significant yang digunakan adalah 0,05 (5\%). Apabila probabilitas signifikansi lebih kecil dari 0,05 maka H0 ditolak dan H1 diterima. Berdasarkan Tabel 7. maka hasil pengujian secara parsial masing-masing variabel independen terhadap dependen dapat dijabarkan sebagi berikut.

Hasil analisis menunjukan koefisien regresi motivasi karir memiliki tanda positif dengan tingkat signifikansi sebesar $0,009<0,05$. Hal ini menunjukkan bahwa hipotesis pertama $\mathrm{H}_{1}$ dalam penelitian ini diterima. Semakin kuat keinginan seseorang untuk meniti karir maka semakin berminat seseorang tersebut untuk mengikuti PPAk. Dorongan untuk mendapatkan kedudukan serta jabatan karir yang lebih baik dapat meningkatkan minat mahasiswa dalam melanjutkan 
Pendidikan Profesi Akuntansi. Hal ini dapat dipahami karena lulusan PPAk akan memiliki kualifikasi kompetensi profesi yang tentunya akan mendapatkan pengakuan lebih tinggi dari pemberi kerja. Mayoritas mahasiswa akuntansi melihat bahwa PPAk sebagai salah satu sarana pendidikan untuk meningkatkan karir mereka. Hal penelitian ini konsisten dengan penelitian yang dilakukan Nisa (2012), Rita dan Indiarto (2013), dan Yudhistira (2014) menunjukkan bahwa motivasi karir berpengaruh positif terhadap minat mahasiswa akuntansi untuk mengikuti PPAk. Berdasarkan hal tersebut, dapat disimpulkan bahwa motivasi karir berpengaruh positif pada minat mahasiswa akuntansi untuk mengikuti PPAk.

Hasil analisis menunjukan koefisien regresi motivasi mengikuti USAP memiliki tanda positif dengan tingkat signifikansi sebesar $0,007<0,05$. Hal ini dapat dijelaskan karena persyaratan mengikuti USAP, semakin kuat keinginan seseorang untuk mengikuti USAP maka semakin berminat seseorang tersebut untuk mengikuti PPAk. Hal penelitian ini konsisten dengan penelitian yang dilakukan Lisnasari dan Fitriany (2008), Raminten (2012) yang menyatakan bahwa motivasi mengikuti USAP mempunyai pengaruh terhadap minat mahasiswa akuntansi untuk mengikuti pendidikan profesi akuntansi (PPAk).Berdasarkan hal tersebut, dapat disimpulkan bahwa motivasi mengikuti USAP berpengaruh positif pada minat mahasiswa akuntansi untuk mengikuti PPAk.

Hasil analisis menunjukan koefisien regresi motivasi kualitas memiliki tanda positif dengan tingkat signifikansi sebesar $0,014<0,05$. Hal ini menunjukkan bahwa semakin kuat motivasi kualitas maka semakin berminat 
Putu Ayu Bella Febryanti A. dan Ketut Alit Suardana. Pengaruh...

seseorang tersebut untuk mengikuti PPAk. Penelitian ini konsisten dengan penelitian yang dilakukanKusumastuti dan Waluyo (2013) mengenai motivasi kualitas menunjukkan bahwa motivasi kualitas berpengaruh positif pada minat mahasiswa akuntansi untuk mengikuti PPAk. Penelitian yang dilakukan oleh Aryani dan Erawati (2016) menunjukkan bahwa motivasi kualitas berpengaruh positif pada minat untuk mengikuti PPAk. Berdasarkan hasil penelitian tersebut dapat disimpulkan bahwa dalam membuat keputusan untuk melanjutkan ke tingkat pendidikan berikutnya, mahasiswa akuntansi mungkin dipengaruhi oleh keinginan untuk meningkatkan kualitas dirinya. Mahasiswa akuntansi mempertimbangkan bahwa PPAk merupakan salah satu sarana untuk meningkatkan kualitas.

Hasil analisis menunjukan koefisien regresi motivasi ekonomi memiliki tanda positif dengan tingkat signifikansi sebesar $0,023<0,05$. Hal ini menunjukkan bahwa semakin kuat motivasi ekonomi maka semakin berminat seseorang tersebut untuk mengikuti PPAk. Hal penelitian ini konsisten dengan penelitian yang dilakukan Kusumastuti (2013) yang menyatakan bahwa motivasi ekonomi berpengaruh positif dan signifikan pada minat mahasiswa akuntansi mengikuti PPAk. Aryani (2016) menyatakan motivasi ekonomi berpengaruh positif pada minat mahasiswa mengikuti PPAk. Lulusan PPAk dianggap atau dipersepsikan akan mendapatkan penghargaan atau kompensasi yang lebih tinggi. Berdasarkan pembahasan tersebut, dapat disimpulkan bahwa mahasiswa akuntansi menganggap bahwa PPAk sebagai legitimasi seseorang untuk menyandang gelar 
akuntan yang merupakan pintu awal untuk memulai karir dengan kesempatan memperoleh penghasilan serta kebutuhan dasar yang lebih besar.

Hasil analisis menunjukan koefisien regresi pengetahuan UU No.5 tahun 2011 memiliki tanda positif dengan tingkat signifikansi sebesar $0,009<0,05$. Hal ini menunjukkan bahwa semakin kuat pengetahuan UU No.5 tahun 2011 tentang akuntan publik maka semakin berminat seseorang tersebut untuk mengikuti PPAk. Hal penelitian ini konsisten dengan penelitian yang dilakukan Kusumastuti dan Indarto (2013) dan Sherlynda (2016) menunjukkan bahwa pengetahuan mahasiswa jurusan akuntansi tentang UU No. 5 Tahun 2011 berpengaruh positif pada minat mahasiswa akuntansi mengikuti PPAk.

\section{SIMPULAN}

Berdasarkan pembahasan hasil penelitian di atas, dapat disimpulkan bahwa motivasi karir, motivasi mengikuti usap, motivasi kualitas, motivasi ekonomi, dan pengetahuan UU No.5 Tahun 2011 tentang akuntan publik berpengaruh positif signifikan pada minat mahasiswa akuntansi mengikuti PPAk. Sedangkan saran yang dapat diberikan adalah bagi perguruan tinggi perlu memperkenalkan tentang profesi akuntan dan PPAk kepada peserta didik sejak dini. Perguruan tinggi perlu untuk menjelaskan lebih dalam lagi akan keuntungan PPAk dari segi peningkatan kualitas, agar nantinya hasil yang mereka peroleh dari mengikuti PPAk sesuai dengan harapan dan motivasi awal yang mereka miliki.

\section{REFERENSI}

Arifianto, F. (2014). Pengaruh Motivasi Diri Dan Persepsi Mengenai Profesi Akuntan Publik Terhadap Minat Menjadi Akuntan Publik Pada Mahasiswa Prodi Akuntansi Fakultas Ekonomi Universitas Negeri Yogyakarta. Jurnal Nominal, 3(2), 150-161. 
Aryani, N. P. D. dan N. M. A. Erawati. (2016). Pengaruh Motivasi Kualitas, Motivasi Karir, Motivasi Ekonomi, dan Biaya Pendidikan pada Minat mengikuti PPAk. E-Jurnal Akuntansi Universitas Udayana, 16(1), 362-387.

Benny, E. dan Yuskar. (2006). Pengaruh Motivasi terhadap Minat Mahasiswa Akuntansi Untuk Mengikuti Pendidikan Profesi Akuntansi (PPAk): (studi empiris pada Perguruan Tinggi di Padang). Simposium Nasional Akuntansi 9 Padang. Universitas Andalas: Padang.

Dyastari, N. P. S. dan I. K. Yadnyana. (2016). Pengaruh Motivasi pada Minat Mahasiswa Non Akuntansi untuk mengikuti PPAk. E-Jurnal Akuntansi Universitas Udayana, 16(1), 333-361.

Farmer, H. S. (1976). What Inhibits Achievment And Career Motivation In Women. The Counseling Psychologist, 6(2), 12-15

Moorhead, G. and R. W. Griffin. (2014). Prilaku Organisasi. Jakarta: Salemba Empat.

Nisa, N. A. K. (2012). Faktor-Faktor yang Mempengaruhi Minat Mahasiswa Untuk Mengikuti Pendidikan Profesi Akuntansi (PPAk) di Surakarta (Survei Pada Perguruan Tinggi Negri Di Surakarta). Naskah Publikasi, Fakultas Ekonomi Universitas Muhammadiyah Surakarta.

Paisey, N. J. C. (2006). Cutting to the core A reflection upon recent education poliey debates within the Institute of Chartered Accountants in England and Wales. The British Accounting Review Journal, 31-6.

Rahardian, I. (2008). Pengaruh Motivasi terhadap Minat Mahasiswa untuk mengikuti PPAk. Skripsi, Fakultas Ekonomi Akuntansi Universitas Katolik Soegijapranata.

Raminten. (2012). Pengaruh Motivasi terhadap Minat Mahasiswa untuk mengikuti Pendidikan Profesi Akuntansi (PPAk). Juraksi, 1(2), 81-95.

Riani, N. L. dan Fitriany. (2008). Faktor yang Mempengaruhi Minat Mahasiswa Akuntansi untuk Mengikuti Pendidikan Profesi Akuntansi (PPAk).

Rita, K. dan I. Wahyu. (2013). Pengaruh Motivasi dan Pengetahuan UU No.5 Tahun 2011 Tentang Akuntan Publik Terhadap Minat Mahasiswa Akuntansi Mengikuti Pendidikan Profesi Akuntansi (PPAk). Jurnal Nominal, 2(2), 130 .

Robbins, S. P. and A. J. Timothy. (2015). Perilaku Organisasi. Edisi ke-16, Jakarta: Salemba Empat.

Samiaji. (2004). Pengaruh Motivasi Terhadap Minat Mahasiswa Akuntansi Untuk Mengikuti Pendidikan Profesi Akuntansi. Simposium Nasional Akuntansi (SNA) VII, Denpasar Bali, 2-3 Desember 2004. 
Sherlynda, B. (2016). Pengaruh Motivasi dan Pengetahuan Undang-Undang No.5 tahun 2011 tentang Akuntan Publik terhadap Minat Mahasiswa Akuntansi mengikuti PPAk. Jurnal Akuntansi Universitas Maritim Raja Ali Haji, 2(12), 1-29.

Siegel dan Marconi. (1991). Behavioral Accounting. South Western Publishing Company.

Slameto. (2010). Belajar dan Faktor-Faktor yang Mempengaruhinya. Jakarta: PT. Rineka Cipta.

Sugiyono. (2017). Metode Penelitian Bisnis. Bandung: Alfabeta.

Suprianto, E. dan M. Nikmahi. (2013). Analisis Faktor-Faktor Yang Mempengaruhi Minat Mahasiswa Akuntansi Untuk Mengikuti Pendidikan Profesi Akuntansi Ditinjau Dari Gender Dan Status Akreditasi Program Studi. Jurnal Akuntansi Indonesia, 2(1).

Surat Keputusan Menteri Pendidikan dan Kebudayaan RI No.179/U/2001 tertanggal 21 November 2001 tentang Penyelenggaraan Pendidikan Profesi Akuntansi.https://luk.staff.ugm.ac.id/atur/Permen179-U-2001ProfesiAkuntan. Diakses pada tanggal 10 November 2017.

Tengker, V.s.g dan J. Marosa. (2007). Pengaruh Motivasi Karir Terhadap Minat Mahasiswa Akuntansi Untuk Mengikuti Pendidikan Profesi Akuntansi (PPAk). Jurnal Akuntansi.

Undang-undang Nomor 34 tahun 1945 tentang Pemakaian Gelar Akuntan. http://iaiglobal.or.id/v03/image/ca/uu_no_34_1954-1. Diakses pada tanggal 10 Juli 2017.

Wheeler, K. G. (1983). Perceptions of Labour Market Variables by College Student in Business, Education, and Psychology. Journal of Vocational Behavior, 22(2), 1-11.

Widyastuti. (2004). Pengaruh Motivasi Terhadap Minat Mahasiswa Akuntansi Untuk Mengikuti Pendidikan Profesi Akuntansi. Simposium Nasional Akuntansi VII, 320-335.

Wlodkowski, R. J. (1981). Making sense our of motivation: A systematic model to consolidate motivational constructs across theories. Educational Psychologist, 16(2), 101-110.

Yudhistira, B. P. (2014). Pengaruh Motivasi Terhadap Minat Mahasiswa untuk Mengikuti Pendidikan Profesi Akuntansi (Studi Empiris pada Mahasiswa Akuntansi Universitas Brawijaya). Jurnal Ilmiah Mahasiswa, 2(2). 